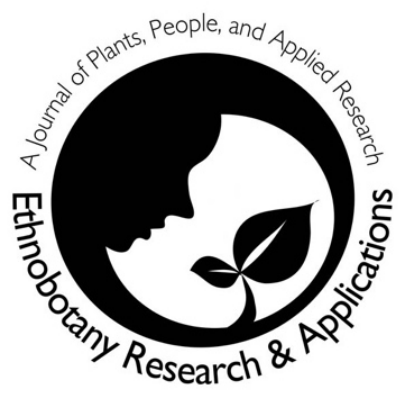

\title{
Sacred weeds: common ritual plants from the urban botánicas of Miami-Dade County, Florida
}

\author{
Barbara Herrera, Alan R. Franck and Cara A. Rockwell
}

Correspondence

Barbara Herrera ${ }^{1}$, Alan R. Franck ${ }^{2}$, Cara A. Rockwell ${ }^{3}$

${ }^{1}$ Department of Earth and Environment, Agroecology Program, Florida International University, Miami, FL 33199, USA

${ }^{2}$ Institute of Environment, Department of Biological Sciences, Florida International University, Miami, FL 33199, USA

${ }^{3}$ Institute of Environment, Florida International University, Miami, FL, USA 33199

*Corresponding Author: crockwel@fiu.edu

Ethnobotany Research \& Applications 22:07 (2021)

\section{Research}

\begin{abstract}
Background: Practitioners of syncretic religions often incorporate plants into their sacred rituals, a unique practice that helps keep them connected to their cultural history. An important example of ritual plant use is found in the botánicas (religious stores that cater to practitioners of Afro-Caribbean diaspora religions) of Miami-Dade County, Florida (USA).
\end{abstract}

Methods: We examined ritual plants sold in a sample of six botánicas in Miami-Dade County from November 2018 until April 2019. We addressed the following questions: 1) What is the ratio of native to non-native plant species found in the botánica stores; 2 ) What is the ratio of invasive exotic to non-invasive exotic plant species found in the botánica stores; and 3) What is the geographical origin of plant species found in the botánica stores?

Results: Given the study's location in South Florida, the frequency of local native flora sold as ritual plants was significantly smaller than initially predicted (27\% vs. $65 \%)$. Likewise, actual frequency of invasive species was much higher than the expected frequency (32\% vs. 19\%). We also discovered that most of the taxa collected during the study were Neotropical (50\%) and Asian (25\%) in origin, while very few African taxa were documented (7 out of the 93 species identified).

Conclusion: These botánicas highlight the reliance of Afro-Caribbean syncretic religions in Miami-Dade County on locally common plants, particularly those taxa from the Neotropics. Future studies should further investigate how these plants are being cultivated, traded, and used by the informal economy associated with urban botánicas.

Keywords: African diaspora, economic botany, ethnobotany, medicinal plants, religious syncretism

\section{Resumen}

Antecedentes: A menudo los practicantes de religiones sincréticas incorporan plantas en sus rituales sagrados. Esta es una práctica única que los ayuda a permanecer conectados con su historia cultural. Un ejemplo importante de uso de las plantas en sus rituales se confirman con la existencia de las botánicas (tiendas que atienden a los practicantes de las diferentes religiones que conforman la diáspora afrocaribeña) del condado de Miami-Dade, Florida (EE.UU.). 
Métodos:

Examinamos las plantas usadas para rituales vendidas en una muestra de seis botánicas en el condado de MiamiDade entre noviembre de 2018 y abril de 2019. Planteamos las siguientes preguntas: 1) ¿Cuál es la proporción de las especies de plantas nativas y no nativas que se ofrecen en las botánicas? 2) ¿Cuál es la proporción de las especies de plantas exóticas invasoras y exóticas no invasivoras que se ofrecen en las botánicas? y 3)¿Cuál es el origen geográfico de las especies vegetales que se ofrecen y venden en las tiendas botánicas?

Resultados: Dada la ubicación del estudio en el sur de Florida, la frecuencia de la flora nativa vendida para rituales fue significativamente menor de lo que se esperaba inicialmente ( $27 \%$ vs. $65 \%)$. Igualmente, la frecuencia real de especies invasoras fue mucho mayor que la esperada (32\% vs. 19\%). También descubrimos que la mayoría de los taxones recolectados durante el estudio son de origen neotropical (50\%) y asiático (25\%), mientras que se documentaron muy pocos taxones de origen africano (7 de las 93 especies identificadas).

Conclusiones. Estas botánicas destacan la dependencia de las religiones sincréticas afrocaribeñas del condado de Miami-Dade en las plantas localmente comunes, en particular los taxones neotropicales. Los estudios futuros deberían investigar más a fondo cómo estas plantas son cultivadas, comercializadas y utilizadas por la economía informal asociada con las botánicas urbanas.

Palabras claves. Botánica económica, diáspora africana, etnobotánica, plantas medicinales, sincretismo religioso.

\section{Background}

Complex layers of cultural, practical, and spiritual ties often govern our relationship with plants (Scott 1974). Indeed, the use of plants has long been pivotal to the social and cultural development of humans, including the evolution of religious beliefs that have incorporated botanical knowledge into ritual practices (see Miller et al. 2019). Archeological records provide evidence for ritual use of plants as early as 13,500 years ago (Iriarte-Chiapusso et al. 2015). Like the agricultural and medicinal plant transfers that have occurred throughout human history (see Beinart \& Middleton 2004, Van Andel 2010), the use of sacred plants has also spread through trade and immigration routes. This global trajectory has fueled not only the diversity of these economic plant species, but also the cross-cultural botanical knowledge that governs their use in religious practices.

Starting in the early sixteenth century, ancient West African ethnobotanical practices and knowledge made the treacherous Middle Passage, the sea journey in which 11 million Africans were transported against their will and enslaved in the New World (Carney 2013, McClure 1982). It is without question that a great number of Old-World food staples were dispersed by enslaved Africans across the Americas during this time (e.g., Oryza glaberrima Steud.; see Carney 2013, Carney \& Rosomoff 2009, Van Andel 2010), ultimately contributing to the growing agricultural economy and the culinary traditions of the New World. Nonetheless, the ability to transport a complete botanical pharmacopeia for ritual and medicinal purposes from the shores of West Africa was likely limited (but see Van Andel et al. 2016, 2019). Thus, enslaved Africans potentially faced a dearth of Old-World plant taxa with known religious and medicinal purposes in their new homeland (Voeks 1997). To overcome this obstacle, some authors have suggested that enslaved people and their descendants used the environmental knowledge of OldWorld plants to identify New World flora for religious and medicinal needs. For example, Van Andel et al. (2014) demonstrated that names for certain Surinamese flora used by modern day Maroons (descendants of escaped Africans in Suriname) correspond to the vernacular names of related African taxa. Results from this study support the hypothesis that Old World botanical knowledge (in concert with contact with local indigenous tribes; see Hoffman 2013) assisted in the Maroons' ancestors' transition to the New World pharmacopeia.

The adaptation to the vast array of New World plants was not the only cultural transition to arise out of this complicated and tragic period of human migration. The fusion of religious practices that flourished in the colonies had its roots in the animistic religions of enslaved Africans and the Roman Catholicism of the European colonists. Prominent examples of New World syncretic religions (e.g., Obeah; McClure 1982, Murrell 2010) evolved during the colonial period, when Catholicism was forced onto enslaved Africans (Odeyemi 2019). While they adopted the foreign religion, they secretly retained their African beliefs and practices (Voeks 1997). In masking the names of their deities, enslaved Africans deceived their colonizers into thinking that they were worshiping Catholic saints (Odeyemi 2019). Despite their dire conditions, this religious transformation allowed them to claim ownership of their faith. 
One of the primary facets of African diasporic religions has been the connection to the spiritual world, through sacrifices of animals (Lammoglia 2008), divination (allowing deities to possess the body), and by ritual baths, also known as "limpieza"(Alanamu 2013) in Spanish or "lavage" in French Creole tradition. The cleaning of the body is a common ritual across the Caribbean in which one bathes oneself with an infusion of different ritual plants, typically ones that are aromatic (Hodges \& Bennett 2006). This sacred rite occurs when another person has inflicted evil upon an individual or when an individual wishes to protect oneself from evil spirits or "el mal de ojo" (or "bad eye"). Another example of a religious practice that has made its way into Afro-Caribbean syncretic religions is "ofrendas", a practice that incorporates plants or other items of value that the practitioner provides to their pantheon of deities in an attempt to continue the bond between the believer and deity in question (Hodges \& Bennett 2006). Older members of Afro-Caribbean and Latin American communities still commonly practice religious rituals such as limpiezas and ofrendas, but these rituals are fading as the older generation's oral history dies with them. Religions such as Vudan (Voodoo) and Santeria are not practiced widely by younger generations, especially given our mobile society and the further separation of kinship (Udo 2020).

Starting in the mid-20 $0^{\text {th }}$ century, clusters of religious stores known as botánicas began to appear in major metropolitan areas, especially those with strong representation from the Latinx and Caribbean communities (Murphy 2015). Botánicas provide practitioners of Afro-Caribbean syncretic religions with ritual objects and plants, as well as plants and plant derivatives for medical ailments (see Reeser \& Cintrón-Moscoso 2013, Viladrich 2006a, 2006b). Despite the prominent role that botánicas play in Miami-Dade County (MDC)'s culture and the growing interest in the cultivation and use of medicinal and ritual plants (Viladrich 2006b), to-date there has been very little documentation on the full array of native and exotic religious plants used in this South Florida county. While other studies have pointed to the conservation and sustainable extraction implications of ritual and medicinal plant collection (e.g., Lima et al. 2016, Melander 2007, Van Andel et al. 2015), the rarity (or conversely, the ubiquity) of the ritual plants of urban botánicas in North America is uncertain.

Accordingly, we addressed the following questions:

1. What is the ratio of native to exotic (naturalized) plant species found in the botánica stores and how does that compare to the ratio of native to exotic (naturalized) plant species found in MDC?

2. What is the ratio of invasive exotic to naturalized (non-invasive) exotic plant species found in the botánica stores and how does that compare to the ratio of invasive exotic to naturalized exotic species found in MDC?

3. What is the geographical origin of the plants found in the botánica stores?

\section{Materials and Methods \\ Study site}

The study was conducted from November 2018-April 2019 in MDC, Florida, an area of approximately $6300 \mathrm{~km}^{2}$ that includes a diverse mix of metropolitan sprawl, natural areas, and agricultural lands. The region is characterized by wet (May-October) and dry (November-April) seasons, with warm subtropical summers and mild winters, similar to other areas of the Caribbean. The region is populated by a rich diversity of immigrants from Latin America (i.e., Mexico, Central America, South America, and Spanish-speaking countries of the Caribbean; Senices 2005) and the Caribbean. The prevalence of Latinx (i.e., those who were born in Latin America and/or their descendants; Salinas and Lozano 2019) and Caribbean people in MDC, paired with the wish to maintain the culture of one's home country, results in cultural-specific stores. A prime example of the Afro-Caribbean/Latinx contribution is the plethora of botánicas in the city (Fig. 1). These stores sell plants, figurines and candles for religious ceremonies and medicinal purposes to a variety of religions and ethnic groups.

\section{Data Collection}

Research was conducted in two Haitian botánicas (Haitian Creole as the major language of commerce), three Hispanic botánicas (Spanish as the major language of commerce) and one integrated botánica (Hispanic owners/ Haitian customers and English as the major language of commerce) to conduct the botanical survey. An initial search for "botánica" on the Google Maps platform (e.g., Hodges \& Bennett 2006) found a total of 86 botánicas in the research area (see Fig. 1). Botánicas were randomly selected to reflect a representative distribution of Hispanic and Haitian stores in Miami. While there are stores and informal markets that focus on other ethnic and/or religious affiliations (e.g., those that cater to Brazilian followers of Candomblé, Obeah practitioners from the Anglophone Caribbean, etc.), they are not as widespread as the Hispanic and Haitian botánicas. Many botánicas offer a variety 
of spiritual and religious items for several different cultures, complicating the identification of a single botánica to a specific syncretic religion or ethnic identity. In general, Hispanic botánicas are far more numerous and widespread in the urban area than those botánicas serving Haitian customers. Clusters of Hispanic botánicas are particularly common in the Little Havana and West Miami neighborhoods of the City of Miami, as well as the municipality of Hialeah (see Fig. 1). While documenting these religious stores, we also noticed that several Haitian botánicas originally selected for the survey were permanently closed in the Little Haiti neighborhood. While there may be several reasons for this trend, this neighborhood is undergoing a rapid transformation in terms of demographics and available services, fueled in part by "climate gentrification", or when wealthier residents and developers seek higher ground in historically impoverished neighborhoods (see Keenan et al. 2018).

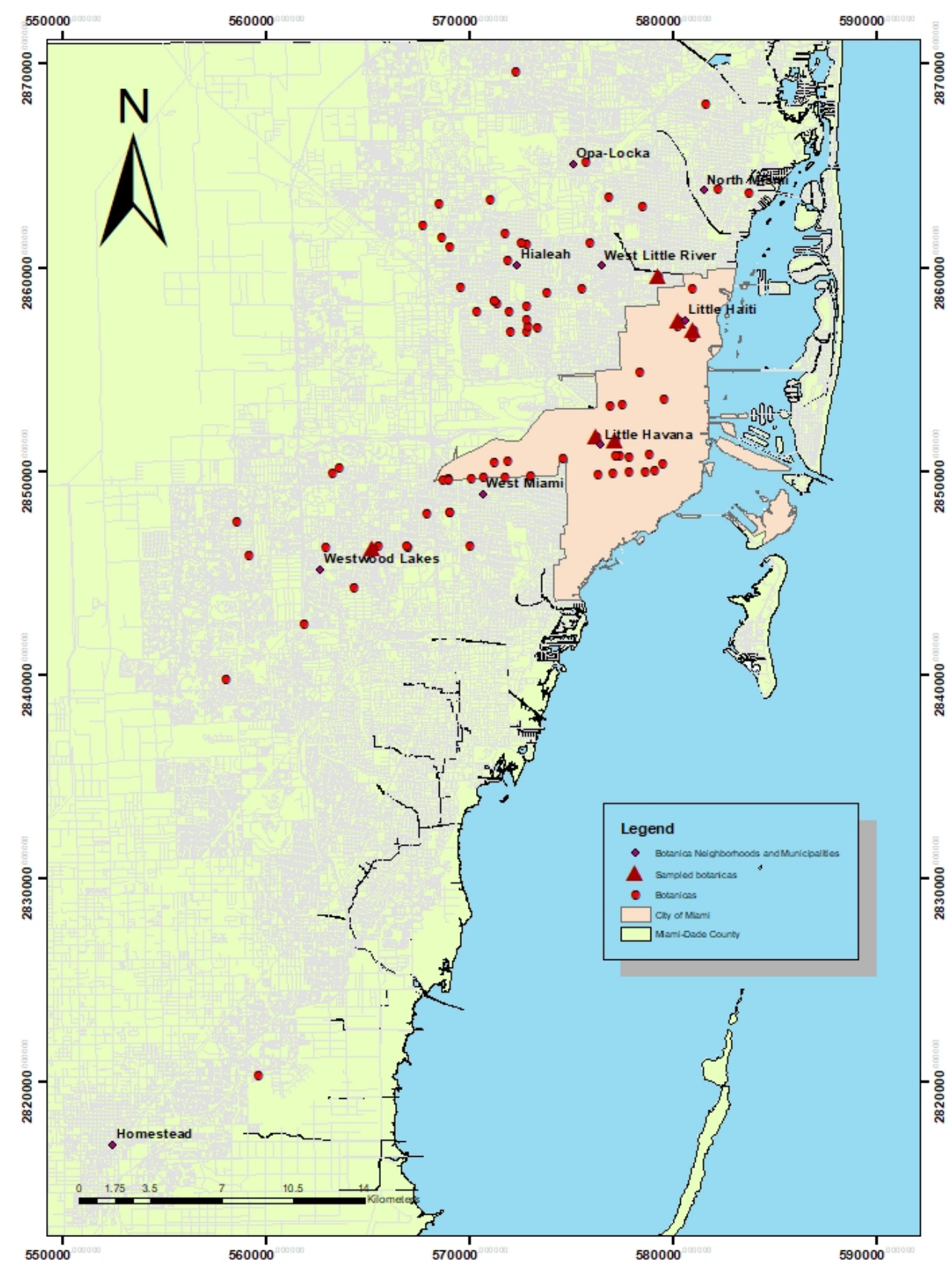

Figure 1. Locations of botánicas in Miami-Dade County, Florida at the time of the study. 
Methods in this ethnobotanical study were adapted from Hodges \& Bennett (2006). When arriving at each botánica, all live plants, dried seeds, fresh and dried leaves, and fruits were collected (Hodges \& Bennett, 2006). Many taxa that we collected are likely used for both religious and medicinal purposes. However, for the purpose of this article, we refer to the plants in question as "ritual plants", given their association with stores whose primary purpose is to sell items of religious importance. Tinctures, soaps, wood, roots, perfumes, and other blended-ingredient products were not collected during these surveys, as we could not identify such products to species. If the species in question was identified as already having been collected at another botánica, the species information was noted down, but no additional collection took place. We were able to purchase plant material online from several of the botánicas chosen for the survey, which avoided the possibility of missing a species that was not available in-store. The availability of certain species of plants varied throughout the course of the study, depending on which day we happened to be visiting a particular botánica. Thus, we visited the botánicas more than once during the collection period to collect additional plants, but it is highly likely we did not collect the full range of ritual plants available to practitioners.

\section{Species identification}

We organized the plant samples by store and labeled them with date of purchase, scientific name, and the common name referenced by the botánicas. We identified each individual sample to species and made botanical vouchers. All botanical vouchers were deposited as a reference collection in the Florida International University (FIU) International Center for Tropical Botany herbarium at Kampong Garden (Coconut Grove, FL).

\section{Data analysis \\ Chi-square analysis}

We analyzed the 93 plants collected and identified to species during this study to compare the expected ratio of MDC native to exotic (naturalized) plants, using the Atlas of Florida Plants (Wunderlin et al. 2021), which seeks to document native and naturalized plants in Florida. It is important to note that when verifying the documented nonnative plants in the Florida Plant Atlas, we did not find several of our exotic species listed, as the Atlas does not include taxa known only from cultivation in Florida. To test the significance of the native vs. exotic comparison, a chi-square test was performed using the R 3.6.0 software platform, adopting methods used by other ethnobotanical studies (e.g., Stepp \& Moerman 2001). We repeated the chi-square analysis to compare the expected ratio of invasive exotic to non-invasive (naturalized) exotic taxa. We verified the invasive status of the flora in question using the Florida Plant Atlas, as well as the Florida Exotic Pest Plant Council database (FLEPPC 2019). The FLEPPC list characterizes the plants as Category 1 (capable of altering native plant communities) or Category 2 (increased in abundance but not altering native plant communities).

\section{Geographic provenance}

Categories of geographic provenance of all 93 plants identified to species during this study were verified using the Kew Royal Botanic Garden Plants of the World online database (Plants of the World Online | Kew Science; accessed January 10, 2021), defined as "Asia", "Europe", "Madagascar", "Mediterranean", "Neotropics", "North America", "Oceania", and "Sub-Saharan Africa". The "Neotropics" category included all plants considered native to the tropical and subtropical climatic zones of the Caribbean, Central America, Mexico, South America, and South Florida. "North America" included temperate, arid, or cold zone taxa that have a widespread geographical range in the North American continent, including South Florida. South Florida presents a unique convergence of temperate and tropical taxa (Browder and Ogden 1999), thus species labelled as MDC "natives" fell under both the "North America" and "Neotropics" categories. Likewise, while Europe claims some portions of the Mediterranean region, we defined the "Mediterranean" category as a distinct climatic class, with respect to its extent on the Asian, African, and European continents. As such, the "Asia" category excluded those plants native to Asian countries and territories in the Mediterranean (e.g., Syria, Lebanon, Israel, and Palestine).

\section{Results and Discussion}

We collected 139 plant specimens across all six botánicas, of which we were able to determine 93 species (see Table 1). The origin of these plants is unclear, although informal conversation with the botánica owners indicated that the plants come from various suppliers (B. Herrera, pers. obs.). Observations of the botánicas and their surroundings would suggest cultivation of these plants could occur onsite, as well. However, due to the informal economy associated with the plant sales, a more precise understanding of the sources of these plants would require a follow up study. 
Table 1. Sampled ritual plant taxa of the botánicas of Miami-Dade County, Florida. FLEPPC Category $1=$ capable of altering native plant communities; FLEPPC Category $2=$ increased in abundance but not altering native plant communities*. "Botánica" column indicates type of botánica where plant was located, based on primary language of commerce at time of study [H=Hispanic (Spanish); Hai=Haitian (Haitian Creole); I=Integrated (English)].

\begin{tabular}{|c|c|c|c|c|c|c|}
\hline Family & Species & $\begin{array}{l}\text { MDC } \\
\text { Native }\end{array}$ & $\begin{array}{l}\text { Naturalized } \\
\text { Exotic }\end{array}$ & $\begin{array}{l}\text { FLEPPC } \\
\text { Invasive }\end{array}$ & Region & Botánica \\
\hline Acanthaceae & Justicia pectoralis Jacq. & & $\sqrt{ }$ & & Neotropics & $\mathrm{H}$ \\
\hline Adoxaceae & Sambucus canadensis $\mathrm{L}$. & $\sqrt{ }$ & & & North America & $\mathrm{H} / \mathrm{I}$ \\
\hline \multirow[t]{4}{*}{ Amaranthaceae } & Amaranthus spinosus $\mathrm{L}$. & & $\sqrt{ }$ & & Neotropics & $\mathrm{H}$ \\
\hline & Chenopodiastrum murale (L.) S. Fuentes-B., Uotila \& Borsch & & $\sqrt{ }$ & & Mediterranean & Hai \\
\hline & Dysphania ambrosioides (L.) Mosyakin \& Clemants & & $\sqrt{ }$ & & Neotropics & $\mathrm{H} / \mathrm{Hai}$ \\
\hline & Mangifera indica $\mathrm{L}$. & & $\sqrt{ }$ & & Asia & $\mathrm{H}$ \\
\hline Annonaceae & Annona squamosa $\mathrm{L}$. & & & & Neotropics & $\mathrm{H}$ \\
\hline \multirow[t]{2}{*}{ Araceae } & Colocasia esculenta (L.) Schott & & $\sqrt{ }$ & 1 & Asia & $\mathrm{H} / \mathrm{I}$ \\
\hline & Pistia stratiotes $\mathrm{L}$. & $\sqrt{ }$ & & & Neotropics & $\mathrm{H}$ \\
\hline Asphodelaceae & Aloe vera (L.) Burm. f. & & & & Asia & Hai \\
\hline \multirow[t]{7}{*}{ Asteraceae } & Ambrosia artemisiifolia L. & $\sqrt{ }$ & & & North America & Hai/l \\
\hline & Baccharis halimifolia L. & $\sqrt{ }$ & & & North America & $\mathrm{H}$ \\
\hline & Bidens alba (L.) DC. & $\sqrt{ }$ & & & Neotropics & $\mathrm{H}$ \\
\hline & Chromolaena odorata (L.) R.M. King \& H. Rob. & $\sqrt{ }$ & & & Neotropics & $\mathrm{H}$ \\
\hline & Eclipta prostrata (L.) L. & $\sqrt{ }$ & & & North America & $\mathrm{H} / \mathrm{I}$ \\
\hline & Koanophyllon villosum (Sw.) R.M. King \& H. Rob. & $\sqrt{ }$ & & & Neotropics & $\mathrm{H}$ \\
\hline & Parthenium hysterophorus $\mathrm{L}$. & & $\sqrt{ }$ & & Neotropics & $\mathrm{H}$ \\
\hline Boraginaceae & Heliotropium indicum $\mathrm{L}$. & & $\sqrt{ }$ & & Neotropics & $\mathrm{H}$ \\
\hline Brassicaceae & Lepidium virginicum $\mathrm{L}$. & $\sqrt{ }$ & & & North America & 1 \\
\hline Bromeliaceae & Tillandsia flexuosa Sw. & $\sqrt{ }$ & & & Neotropics & $\mathrm{H}$ \\
\hline Burseraceae & Bursera simaruba (L.) Sarg. & $\sqrt{ }$ & & & Neotropics & $\mathrm{H}$ \\
\hline Caricaceae & Carica papaya L. & $\sqrt{ }$ & & & Neotropics & $\mathrm{H}$ \\
\hline Clusiaceae & Garcinia kola Heckel & & $\sqrt{ }$ & & Sub-Saharan Africa & $\mathrm{H}$ \\
\hline Combretaceae & Terminalia catappa L. & & $\sqrt{ }$ & 2 & Asia & $\mathrm{H}$ \\
\hline \multirow[t]{2}{*}{ Commelinaceae } & Commelina diffusa Burm. f. & & $\sqrt{ }$ & & Asia & $\mathrm{H}$ \\
\hline & Tradescantia zebrine hort. ex Bosse & & $\sqrt{ }$ & & Neotropics & $\mathrm{H}$ \\
\hline Crassulaceae & Kalanchoe pinnata (Lam.) Pers. & & $\sqrt{ }$ & 2 & Madagascar & $\mathrm{H}$ \\
\hline Cucurbitaceae & Momordica charantia L. & & $\sqrt{ }$ & 2 & Asia & $\mathrm{H}$ \\
\hline Cyperaceae & Cyperus involucratus Rottb. & & $\sqrt{ }$ & 2 & Madagascar & $\mathrm{H}$ \\
\hline Dioscoreaceae & Dioscorea bulbifera L. & & $\sqrt{ }$ & 1 & Sub-Saharan Africa & Hai \\
\hline \multirow[t]{6}{*}{ Euphorbiaceae } & Acalypha arvensis Poepp. & & $\sqrt{ }$ & & Neotropics & $\mathrm{H}$ \\
\hline & Cnidoscolus aconitifolius (Mill.) I.M. Johnst. & & $\sqrt{ }$ & & Neotropics & 1 \\
\hline & Codiaeum variegatum (L.) Rumph. ex A. Juss. & & $\sqrt{ }$ & & Asia & $\mathrm{H}$ \\
\hline & Euphorbia tithymaloides $\mathrm{L}$. & & $\sqrt{ }$ & & Neotropics & I \\
\hline & Hura crepitans L. & & & & Neotropics & $\mathrm{H}$ \\
\hline & Jatropha curcas L. & & $\sqrt{ }$ & & Neotropics & H/Hai/l \\
\hline
\end{tabular}


Ethnobotany Research and Applications

Jatropha gossypifolia L.

Ricinus communis $\mathrm{L}$.

Fabaceae

Malvaceae

Meliaceae

Moraceae

Moringaceae

Myrtaceae

Nyctaginaceae

Petiveriaceae

Piperaceae

Plantaginaceae

Plumbaginaceae

Poaceae

Portulacaceae

Rubiaceae

Rutaceae

Rutaceae

Melia azedarach L.
Abrus precatorius L.

Ceratonia silique L.

Delonix regia (Bojer ex Hook.) Raf.

Guilandina bonduc L.

Mimosa pudica L.

Mentha spicata L.

Ocimum basilicum L.

Ocimum kilimandscharicum Baker ex Gürke

Ocimum tenuiflorum Burm. f.

Plectranthus amboinicus (Lour.) Spreng.

Pogostemon cablin (Blanco) Benth.

Salvia officinalis L

Salvia rosmarinus Schleid.

Vitex trifolia L.

Persea americana Mill.

Abutilon theophrasti Medik.

Ceiba pentandra (L.) Gaertn.

Cola nitida (Vent.) Schott \& Endl.

Gossypium hirsutum L.

Hibiscus rosa-sinensis L.

Ficus altissima Blume

Ficus benjamina L.

Ficus religiosa $\mathrm{L}$

Moringa oleifera Lam.

Psidium guajava $\mathrm{L}$.

Syzygium jambos (L.) Alston

Boerhaavia diffusa L.

Mirabilis jalapa L.

Petiveria alliacea $\mathrm{L}$.

Pilea microphylla (L.) Liebm.

Peperomia pellucida (L.) Kunth

Piper umbellatum $\mathrm{L}$

Plantago major $\mathrm{L}$.

Plumbago auriculata Lam.

Cymbopogon citratus (DC.) Stapf

Portulaca oleracea L.

Hamelia patens Jacq

Murraya paniculata (L.) Jack

Ruta chalepensis
Neotropics

Sub-Saharan Africa

Asia

Asia

Madagascar

Neotropics

Neotropics

Mediterranean

Asia

Sub-Saharan Africa

Asia

Sub-Saharan Africa

Asia

Mediterranean

Mediterranean

Neotropics

Asia

Neotropics

Sub-Saharan Africa

Neotropics

Asia

2
2

Asia

Asia

Asia

Asia

Asia

Neotropics

Asia

Neotropics

Neotropics

Neotropics

Neotropics

Neotropics

Asia

Europe

Sub-Saharan Africa

Asia

North America

Neotropics

Asia

Mediterranean
Hai

$\mathrm{H}$

$\mathrm{H} / \mathrm{I}$ 


\section{Ethnobotany Research and Applications}

$\begin{array}{ll}\text { Sapindaceae } & \text { Sapindus saponaria L. } \\ \text { Sapotaceae } & \text { Chrysophyllum cainito L. } \\ & \text { Pouteria campechiana (Kunth) Baehni } \\ & \text { Pouteria sapota (Jacq.) H.E. Moore \& Stearn } \\ \text { Selaginellaceae } & \text { Selaginella lepidophylla (Hook. \& Grev.) Spring } \\ \text { Solanaceae } & \text { Brugmansia suaveolens (Humb. \& Bonpl. ex Willd.) Sweet } \\ & \text { Datura stramonium L. } \\ & \text { Nicotiana tabacum } \mathrm{L} . \\ & \text { Solanum diphyllum } \mathrm{L} . \\ & \text { Solanum torvum Sw. } \\ \text { Urticaceae } & \text { Cecropia schreberiana Miq. } \\ \text { Verbenaceae } & \text { Duranta repens L. } \\ & \text { Lantana strigocamara R.W. Sanders } \\ & \text { Lippia dulcis Trevir. } \\ & \text { Stachytarpheta cayennensis (Rich.) Vahl }\end{array}$

Neotropics

Neotropics

North America

Neotropics

Neotropics

Neotropics

Neotropics

Neotropics

Neotropics

Neotropics

Lantana strigocamara R.W. Sanders

Neotropics

Stachytarpheta cayennensis (Rich.) Vah

Neotropics

Neotropics

*Invasive categories designations based on FLEPPC 2019. 
Common names in our study were often associated with more than one species across the botánicas (e.g., both Ficus altissima and Ficus aurea were sold at the same botánica under "jaguey"). Additionally, we encountered on more than one occasion specimens with a common name in Spanish that closely resembled botanical nomenclature (e.g., Ceiba pentandra (L.) Gaertn. is typically sold as "ceiba" in Hispanic botánicas), but which nonetheless ended up being a completely different species (or family). Most notably, these examples included Ambrosia artemisiifolia L. (labelled "artemisia" in the botánica where it was sampled), Stachytarpheta cayennensis (Rich.) Vahl (labelled "verbena"), and Ficus benjamina L. (labelled "laurel'). In the cases of $A$. artemisiifolia and S. cayennensis, these species are not as well known for medicinal properties as species of Artemisia and Verbena (but see Froelich et al. 2008, Schapoval et al. 1998), but they are in the same families (Asteraceae and Verbenaceae, respectively). In the instance of F. benjamina, the species is not even in the same family that one would expect with a name like "laurel" (typically, Lauraceae); it is in the Moraceae family. This discrepancy is even more disconcerting because the consumption of fresh fig leaves (or any other part of the plant containing sap) can lead to serious consequences for those with an allergy to latex (Hemmer et al. 2004).

The most common family (out of 44) was determined to be the mint family (Lamiaceae; 10\%), closely followed by Euphorbiaceae (9\%) and Asteraceae (8\%). It is worth mentioning that these botanical families have long been recognized as some of the world's most common medicinal plant families (Kindscher et al. 2013, Lima et al. 2016, Polat 2019, Thomas et al. 2009). Additionally, they have demonstrated pharmacological compounds and medicinal capacities via a combination of oral tradition and medical research results (Koc et al. 2014, Shing et al. 2002). Given that many of the plants collected in the botánicas are often used in the preparation of tinctures for the limpieza ritual, one would also expect the selected plants to be fragrant (thus explaining the abundance of Lamiaceae species, especially those in the Ocimum genus). These botanical families are also some of the largest in the world; thus, the probability of their value as medicinal and spiritual plants is much higher than other groups, based on their availability alone.

We found only three species that were common across the botánica categories (Hispanic, Haitian, and Integrated): Ruta chalepensis L., Ocimum kilimandscharicum Baker Gürke, and Mimosa pudica L., all of which are considered important medicinal taxa (Chaturvedi et al. 2017, lauk et al. 2004, Muhammad et al. 2016, Nigam et al. 2019). R. chalepensis and $O$. kilimandscharicum are also fragrant plants that are likely favored for cleaning rituals, but further investigation is needed to understand the cultural importance of these plants. We also observed that the Haitianspecific botánicas were smaller than the Hispanic botánicas, a factor (in concert with low sample size) that could explain the paucity of taxa collected in the Haitian botánicas (11 species, Table 1). We realize that six botánicas is not a substantial number comparative to the 86 found within MDC, yet when we attempted to augment the number of sampled botánicas, we discovered that many of the Haitian botánicas were permanently closed, thus limiting our ability to make a broad comparison across the botánicas. Additionally, these cultural stores often rely on word of mouth, increasing the difficulty in pinpointing their location or contact information. An increase in sample size across the Spanish and Haitian-specific stores would certainly lend well to a more thorough understanding of the diversity of plant use across the span of Afro-Caribbean syncretic religions. Nonetheless, despite the aforementioned limitations, our study offers a vivid snapshot of the plant diversity found within the MDC botánica community.

\section{Native vs. exotic (naturalized) taxa}

The ratio of MDC native to naturalized exotic plants was compared to the same ratio of plants found in the botánicas. The sum of 93 documented taxa did not include any repeated plants, as to avoid discrepancies in the analysis. This resulted in a total of 73 exotic and 20 native plant species documented from the botánicas, including native taxa that have a widespread range in both North America and the Neotropics (Table 1). Given that we were using the Florida Plant Atlas to make our comparison, we removed cultivated exotics that to-date have not been found in the wild from the analysis. This narrowing of the exotic category reduced the total number of naturalized exotic species to 54 . The ratio of native vs. naturalized exotic plants in the botánicas (20 vs. 54), when compared to the expected ratio of 1221 native and 669 exotic plant taxa found in MDC (Table 2), was significant $(p \leq 0.0001)$. This result indicates that the percentage of native plant taxa found in the botánicas was lower than expected, especially given the high diversity of native species in the subtropical climate of MDC (Browder and Ogden 1999).

Despite the relatively low number of native taxa documented for this study, their presence in the botánicas was not completely unexpected. The taxa in question are not endemic to MDC. Rather, most of the identified South Florida natives in this study are widespread throughout the Caribbean. Thus, it is likely that many botánica clientele had already encountered many of these MDC taxa prior to settling in South Florida, potentially ensuring a 
"continuity of knowledge" concerning traditional folk pharmacopeias (see Ceuterick et al. 2008, Fonseca \& Balick 2018). The question then remains as to why local taxa are not being used by the botánica clientele. In their 2018 study, Fonseca \& Balick demonstrated that Candomblé practitioners in New York City were maintaining a high level of cultural continuity regarding the traditional botanical pharmacopeia, while also slowly incorporating plant species of their adopted homeland. The authors suggest that cultural familiarity seemed to play a much stronger role in plant selection than just availability. It is possible that a similar situation is guiding trends in the botánica plant market in MDC, but this can only be confirmed via a longer-term study that includes ethnographic interviews with practitioners and vendors.

Table 2. Expected proportion of native to exotic (naturalized) species in local botánicas of Miami-Dade County (MDC), Florida (X: 43.2; $\mathrm{P} \leq .0001 ;$ Df: 1$)$.

\begin{tabular}{lllll}
\hline Plant Source & Native & Exotic & Total & $\begin{array}{l}\text { Proportion of MDC } \\
\text { Natives }\end{array}$ \\
\hline Botánica & 20 & 54 & 74 & $27 \%$ \\
MDC & 1221 & 669 & 1890 & $65 \%$
\end{tabular}

*MDC native vs. exotic (naturalized) designations based on Wunderlin et al. 2021.

\section{Invasive exotic vs. naturalized (non-invasive) exotic taxa}

The ratio of invasive to non-invasive naturalized exotic plants commonly found in MDC was compared to that of plants collected from the botánicas (Table 3). A total of five Category 1 (exotics considered capable of altering native plant communities) FLEPPC species and 12 Category 2 (those exotics that have increased abundancy but have yet to alter native plant communities) FLEPPC taxa were found in our survey (Table 1). These 17 species are included in the total count of 54 naturalized taxa, out of the 73 exotic species identified this study. Results of the chi square analysis were significant $(p=0.03)$, indicating that the proportion of invasive plants from the botánicas was greater than the proportion of invasive exotic taxa (compared to non-invasive exotic species) in MDC (32\% vs. $19 \%$, respectively).

Table 3. Expected proportion of invasive vs. non-invasive exotic (naturalized) species in local botanicas of MiamiDade County (MDC, Florida ( $X$ : 4.8; $P=0.03 ;$ Df: 1 ).

\begin{tabular}{lllll}
\hline Plant Source & Invasive exotics & Non-invasive exotics & Total & Proportion of Invasive Exotics \\
\hline Botánica & 17 & 37 & 54 & $32 \%$ \\
MDC & 128 & 541 & 669 & $19 \%$
\end{tabular}

*Invasive categories designations based on FLEPPC 2019.

Followers of Afro-Caribbean syncretic religions (as well as Neotropical indigenous communities) have historically embraced flora that tend to be abundant, something that has been noted by other authors (e.g., Grimé 1976, McClure 1982, Stepp \& Moerman 2001) and reinforced in this study. The presence of invasive plants supports the idea that practitioners and botánica vendors alike (at least in MDC) veer towards what is common (or "weedy"), rather than what is rare. Only two native species in our collection are considered species of special concern (Koanophyllon villosum (Sw.) R.M. King \& H. Rob., State of Florida endangered; Tillandsia flexuosa SW., State of Florida threatened; Wunderlin et al. 2021). The concept and categorization of weeds has long been a subject of debate; typically, weeds are seen as those plants that are not valued for use or for beauty (Harlan \& deWet 1963). However, as this study demonstrates, even the most noxious "weeds" can have value to the point that people will pay for them. It could even be argued that several of the native flora found in the botánicas would likely be classified as common weeds by most urban Miami inhabitants (e.g., Bidens alba (L.) DC, A. artemisiifolia L.), given their propensity to establish in residents' yards.

\section{Geographic provenance of plant taxa}

Only one species from the temperate climate of Europe (Plantago major L.) was discovered in the collection, followed by three taxa from Madagascar, six from the Mediterranean, and seven species from North America (of which five are considered native to MDC; Table 1). No plants from Oceania were encountered. Geographical origin of most of the recorded medicinal/ritual plants was found to be Neotropical America and Asia ( $50 \%$ and $25 \%$, respectively). Of the total number of Neotropical taxa, $30 \%$ of the plants are considered native taxa of MDC. This 
strong reliance on Neotropical plants is unsurprising, considering that the syncretic religions highlighted in this study originated in the Caribbean region, where many of the collected taxa flourish in the natural environment. Additionally, South Florida is characterized by a subtropical climate, thus facilitating the cultivation of many tropical plants.

We initially hypothesized that we would find a much higher proportion of African plants in the botánicas, following the logic that the ancestral origin of many New World syncretic religions is West African. Instead, we found only seven plants native to sub-Saharan Africa [Cola nitida (Vent.) Schott \& Endl., Dioscorea bulbifera L., Garcinia kola Heckel, O. kilimandscharicum Baker ex Gürke, Plumbago auriculata Lam., Ricinus communis L., and Plectranthus amboinicus Lour.] out of the 93 species highlighted in this study. The native range of four of these African taxa is still uncertain: the geographic provenance of $P$. amboinicus has yet to be verified (with some botanists claiming an origin on the Indian subcontinent, Arumugam et al. 2016), and P. auriculata, $O$. kilimandscharicum, and $R$. communis are likely native to other regions of Africa (rather than the Western coast). Ethnobotanical histories are also complicated by the fact that certain taxa were traded and cultivated in West Africa for several centuries prior to the peak of the New World slave trade. McClure (1982) highlights the example of Abrus precatorius L., an Asian species which was first described as being cultivated in West Africa by the end of the fifteenth century (Pickering 1879); the species is now completely naturalized in the region. Some authors have also mistakenly identified $A$. precatorius as a native of the Caribbean region, based on its abundance in island habitats and quick adoption into the Carib and Arawak cultures (see Grimé 1976).

\section{Conclusions}

Humans have long relied on plants for food, shelter, medicine, and religious practices, with some cultural and ethnic groups even regarding certain floral taxa in anthropomorphic terms (see Hall 2011). This strong bond with plants, in concert with human populations' ability to mobilize, has led to an expansion of plant usage and appreciation across many cultures and geographic regions. Worldwide, practitioners of certain religions continue to incorporate plants into their spiritual routines, even in the face of rapid societal change. For example, migration to new regions has historically forced immigrants to adapt to new environments and modify their practices, including the overhaul of their traditional plant knowledge (Geck et al. 2016). This shift in surroundings can result in minor or major changes taking place in the process of creating a connection between the two cultures.

The transition from rural to urban settings can cause complications, as well. Plants that were once highly accessible for practices such as limpiezas or ofrendas are not as readily available in major cities, especially given the reduced green space associated with urban landscapes (Weckmüller et al. 2019). Accordingly, adaptation to the urban environment has led to a proliferation of botánicas in most major US cities with substantial representation from the Latinx and Caribbean communities (Gomez-Beloz \& Chavez 2001, Viladrich 2006a). These stores (implicitly highlighting the important role of plants via the name) serve as a haven for immigrant communities and their descendants, supplying practitioners with religious articles, tinctures, accessories of worship, plants, and most importantly, a connection to their ancestry.

MDC, Florida represents one of the most diverse metropolitan areas in the United States, with its mosaic of restaurants, local grocery stores, and cultural centers heavily influenced by the neighboring Caribbean and Latin American regions. Currently, it is considered a majority/minority population, with more than two-thirds of the population self-identifying as Latinx (Portes \& Armony 2018). To help understand this community's relationship with plants, we chose to study local botánicas to shed light on certain cultural aspects of plant usage within these religious stores. Our investigation of six botánicas in MDC confirmed that vendors continue to offer plants that are familiar to their customers, regardless of the new environment, especially ones that are considered "weeds" or naturalized (almost $60 \%$ of the taxa in this study).

Indeed, the cultivation of economic plants can be an important indicator of cultural history (McClure 1982). Humans tend to adapt to the environment in which they reside and modify important traditions (including favored plant species and their uses) as a means to carry on a familiar way of life. Nonetheless, despite the resiliency of ethnobotanical knowledge in local immigrant communities, it is possible that these traditions are at risk of becoming lost in the shuffle of urban development in Miami. Long-term residents in historically Latinx and Black neighborhoods are becoming dispersed due to recent trends in climate gentrification (Feldman \& Jolivet 2014), frequently settling in the outer reaches of the city, where housing prices are more affordable. This trend often leads to the loss of community, and subsequently, loss of culture, a phenomenon that is frequently studied but rarely mitigated by policymakers and urban planners. In many cases, the youth of these fractured communities might 
grow up without their ancestral knowledge. Although enculturation can occur from afar, it rarely does (see Ferguson et al. 2016).

As for future studies, investigating the ritual and medicinal plants of the botánicas and their compounds could provide important information and insight into certain medical conditions for modern medicine (e.g., Menard et al. 2010) and into traditional medical practices still maintained by immigrant groups (Reeser \& Cintrón-Moscoso 2013). Additionally, forming a dialogue with the owners of the botánicas could highlight where these plants are being cultivated (or collected), as many of them are considered "weedy" species and are not typically sold in largescale nurseries. Indeed, given that we were not able to sample the full array of plants available to botánica clientele, it is possible that vendors are selling other plants of concern (FLEPPC or native rare taxa) not recorded in this study. As such, outreach to the botánica community will be important to determine if these plants of interest are being cultivated or collected from local parks and backyard gardens. Finally, the uses of these plants (according to different Afro-Caribbean religions) should be explored via communication with practitioners. It is possible that the religious importance of several species has widespread acceptance across different cultures, whilst some have more exclusivity within specific religions. Given the transitions that are taking place in many of these communities, documentation (e.g., increased use of botánicas during pandemics) and transfer of this valuable ethnobotanical knowledge is at a critical crossroads.

\section{Declarations}

List of abbreviations: Not applicable

Ethics approval and consent to participate: No human participants were involved with this study.

Consent for publication: Not applicable.

Availability of data and materials: Vouchers have been deposited at the Florida International University (FIU)'s International Center for Tropical Botany Herbarium at Kampong Garden, Coconut Grove, Florida.

Competing interests: The authors declare no conflict of interest.

Funding: The research was supported by the United States Department of Agriculture (USDA)'s National Institute of Food and Agriculture (NIFA) Hispanic Program 2016-38422-25549.

Authors' contributions: Barbara Herrera: Study design, botanical sample collection and identification, manuscript writing, data management and analysis, data interpretation. Alan Franck: Botanical sample identification, manuscript writing. Cara Rockwell: Study design, student mentoring, botanical sample collection, manuscript writing, data analysis and interpretation.

\section{Acknowledgements}

The authors would like to thank the Tropical Root Ecology and Evolution Lab (FIU Department of Biological Sciences) and the International Center for Tropical Botany Herbarium at Kampong Garden for providing a space to conduct the identification of the samples and storage. Additionally, we would like to thank Dr. Mahadev Bhat, Dr. Krish Jayachandran, Eric Betancourt, and the Agroecology Program (FIU Department of Earth and Environment) for giving Barbara Herrera the opportunity to pursue this undergraduate research project. We also thank Nina Jungman for her revision of the Spanish text. Any opinions, findings, conclusions, or recommendations expressed in this publication are those of the authors and do not necessarily reflect the view of the USDA.

\section{Literature Cited}

Alanamu T. 2013. Indigenous medical practices and the advent of CMS medical evangelism in nineteenth century Yorubaland. Church History \& Religious Culture 93(1):5-27.

Arumugam G, Swamy MK, Sinniah UR. 2016. Plectranthus amboinicus (Lour.) Spreng: botanical, phytochemical, pharmacological and nutritional significance. Molecules 21(4):369.

Beinart W, Middleton K. 2004. Plant transfers in historical perspective: a review article. Environment and History 10(1):3-29.

Browder JA, Ogden JC. 1999. The natural South Florida system II: predrainage ecology. Urban Ecosystems 3:24577.

Carney, J. 2013. Seeds of memory: botanical legacies of the African diaspora. In R. Voeks \& J. Rashford (eds), African ethnobotany in the Americas (pp. 13-33). Springer, New York, NY, 441pp. 
Carney JA, Rosomoff RN. 2009. In the shadow of slavery: Africa's botanical legacy in the Atlantic world. University of California Press, Oakland, CA, 296pp.

Ceuterick M, Vandebroek I, Torry B, Pieroni A. 2008. Cross-cultural adaptation in urban ethnobotany: the Colombian folk pharmacopoeia in London. Journal of Ethnopharmacology 120:342-59.

Chaturvedi T, Kumar A, Kumar A, Verma RS, Padalia RC, Sundaresan V, Chauhan A, Saikia D, Singh VR, Venkatesha K. 2018. Chemical composition, genetic diversity, antibacterial, antifungal and antioxidant activities of camphorbasil (Ocimum kilimandscharicum Guerke). Industrial Crops \& Products 118:246-258.

Feldman M, Jolivet V. 2014. Back to Little Havana: Controlling gentrification in the heart of Cuban Miami. International Journal of Urban and Regional Research 38(4):1266-1285.

Ferguson GM, Costigan CL, Clarke CV, Ge JS. 2016. Introducing remote enculturation: Learning your heritage culture from afar. Child Development Perspectives 10(3):166-171.

FLEPPC. 2019. List of Invasive Plant Species. Florida Exotic Pest Plant Council. www.fleppc.org, accessed October 15, 2020.

Fonseca FN, Balick MJ. 2018. Plant-knowledge adaptation in an urban setting: Candomblé ethnobotany in New York City. Economic Botany 72: 56-70.

Froelich S, Gupta MP, Siems K, Jenett-Siems K. 2008. Phenylethanoid glycosides from Stachytarpheta cayennensis (Rich.) Vahl, Verbenaceae, a traditional antimalarial medicinal plant. Revista Brasileira de Farmacognosia 18(4):51720.

Geck MS, Reyes García AJ, Casu L, Leonti M. 2016. Acculturation and ethnomedicine: A regional comparison of medicinal plant knowledge among the Zoque of southern Mexico. Journal of Ethnopharmacology 187:146-159.

Gomez-Beloz A, Chavez N. 2001. The botanica as a culturally appropriate health care option for Latinos. The Journal of Alternative \& Complementary Medicine 7(5):537-46.

Grimé WE. 1976. Ethno-Botany of the Black Americans. Reference Publications, 237pp.

Hall M. 2011. Plants as Persons: A Philosophical Botany. State University of New York Press, Albany, NY, 248pp.

Harlan JR, deWet JM. 1963. Some thoughts about weeds. Economic Botany 19(1):16-24.

Hemmer W, Focke M, Götz M, Jarisch R. 2004. Sensitization to Ficus benjamina: relationship to natural rubber latex allergy and identification of foods implicated in the Ficus-fruit syndrome. Clinical \& Experimental Allergy. 34(8):1251-8.

Hodges S, Bennett, BC. 2006. The Ethnobotany of Pluchea carolinensis (Jacq.) G. Don (Asteraceae) in the botánicas of Miami, Florida. Economic Botany 60:75-84.

Hoffman, B. 2013. Exploring biocultural contexts: Comparative woody plant knowledge of an indigenous and AfroAmerican Maroon community in Suriname, South America. In R. Voeks \& J. Rashford (eds), African Ethnobotany in the Americas (pp. 335-393). Springer, New York, NY, 441pp.

lauk L, Mangano K, Rapisarda A, Ragusa S, Maiolino L, Musumeci R, Costanzo R, Serra A, Speciale A. 2004. Protection against murine endotoxemia by treatment with Ruta chalepensis L., a plant with anti-inflammatory properties. Journal of Ethnopharmacology 90:267-72.

Iriarte-Chiapusso MJ, Arrizabalaga A, Cuenca-Bescós G. 2015. The vegetational and climatic contexts of the Lower Magdalenian human burial in El Mirón Cave (Cantabria, Spain): implications related to human behavior. Journal of Archaeological Science 60:66-74.

Keenan JM, Hill T, Gumber A. 2018. Climate gentrification: from theory to empiricism in Miami-Dade County, Florida. Environmental Research Letters13: 054001.

Kindscher K, Corbett S, McClure K. 2013. A statistical analysis of medicinal plants: A case study of plant families in Kansas and the Great Plains. Transactions of the Kansas Academy of Science 116(3/4):149-155.

Koc S, Isgor BS, Isgor YG, Shomali Moghaddam N, Yildirim O. 2015. The potential medicinal value of plants from Asteraceae family with antioxidant defense enzymes as biological targets. Pharmaceutical Biology 53(5):746-751. 
Lammoglia JA. 2008. Legal aspects of animal sacrifice within the context of Afro-Caribbean religions. St. Thomas Law Review 20:710-720.

Lima PG, Coelho-Ferreira M, da Silva Santos R. 2016. Perspectives on medicinal plants in public markets across the Amazon: a review. Economic Botany 70(1):64-78.

McClure SA. 1982. Parallel usages of medicinal plants by Africans and their Caribbean descendants. Economic Botany 36(3):291-303.

Melander M. 2007. Endangered plants on the market in Havana City, Cuba. Minor field study, Committee of Tropical Ecology, Uppsala University, Sweden, 30p.

Menard J, Kobetz E, Diem J, Lifleur M, Blanco J, Barton B. 2010. The sociocultural context of gynecological health among Haitian immigrant women in Florida: applying ethnographic methods to public health inquiry. Ethnicity \& Health 15(3):253-67.

Miller MJ, Albarracin-Jordan J, Moore C, Capriles J.M. 2019. Chemical evidence for the use of multiple psychotropic plants in a 1000-year-old ritual bundle from South America. PNAS 116:11207-11212.

Muhammad G, Hussain MA, Jantan I, Bukhari SNA. 2016. Mimosa pudica L., a high-value medicinal plant as a source of bioactives for pharmaceuticals. Comprehensive Reviews In Food Science And Food Safety 15(2):303-315.

Murphy JM. 2015. Botánicas: Sacred spaces of healing and devotion in urban America. Univ. Press of Mississippi, Jackson, MS, 212pp.

Murrell NS. 2010. Afro-Caribbean Religions: An Introduction to Their Historical, Cultural, and Sacred Traditions. Temple University Press, Philadelphia, PA, 432pp.

Nigam M, Atanassova M, Mishra AP, Pezzani R, Devkota HP, Plygun S, Salehi B, Setzer WN, Sharifi-Rad J. 2019. Bioactive compounds and health benefits of Artemisia species. Natural Product Communications 14(7).

Odeyemi JS. 2019. In ancient times, God spoke in different ways to our ancestors and through the prophets: Existential and Ontological Possible Parallels between Yoruba Traditional Religion and the Christ Event. Journal of Ecumenical Studies 54(4):520-538.

Pickering, C. 1879. Chronological History of Plants. Man's record of his own existence illustrated through their names, uses and companionship. Little, Brown, Boston, MA.

Polat R. 2019. Ethnobotanical study on medicinal plants in Bingol (City center) (Turkey). Journal of Herbal Medicine 16: 100211.

Portes A, Armony AC. 2018. The Global Edge: Miami in the Twenty-first Century. University of California Press, Berkeley, CA, 288p.

Reeser DC, Cintrón-Moscoso F. 2013. Immigrant health care niches: Exploring the role of botánicas in Tampa, FL. vis-à-vis: Explorations in Anthropology 12(1):3-19.

Salinas Jr C, Lozano A. 2019. Mapping and recontextualizing the evolution of the term Latinx: An environmental scanning in higher education. Journal of Latinos and Education 18:302-315.

Schapoval EE, de Vargas MR, Chaves CG, Bridi R, Zuanazzi JA, Henriques AT. 1998. Antiinflammatory and antinociceptive activities of extracts and isolated compounds from Stachytarpheta cayennensis. Journal of Ethnopharmacology 60(1):53-59.

Scott CS. 1974. Health and healing practices among five ethnic groups in Miami, Florida. Public Health Reports 89(6):524.

Senices J. 2005. The complexity behind the Hispanic identity. Journal of Applied Rehabilitation Counseling 36(2):20.

Shing B, Sahu PM, Sharma MK. 2002. Anti-inflammatory and antimicrobial activities of triterpenoids from Strobilanthes callosus Ness. Phytomedicine 9:355-359.

Stepp JR, Moerman DE. 2001. The importance of weeds in ethnopharmacology. Journal of Ethnopharmacology.75(1):19-23. 
Thomas E, Vandebroek I, Sanca S, Van Damme P. 2009. Cultural significance of medicinal plant families and species among Quechua farmers in Apillapampa, Bolivia. Journal of Ethnopharmacology 122(1):60-67.

Udo EM. 2020. The vitality of Yoruba culture in the Americas. Ufahamu: A Journal of African Studies 41(2):27doi:10.1017/S0959774300015249

Van Andel TR. 2010. African Rice (Oryza glaberrima Steud.): Lost Crop of the Enslaved Africans Discovered in Suriname. Economic Botany 64(1):1-10.

Van Andel TR, Croft S, Van Loon EE, Quiroz D, Towns AM, Raes N. 2015. Prioritizing West African medicinal plants for conservation and sustainable extraction studies based on market surveys and species distribution models. Biological Conservation 181:173-81.

Van Andel TR, van der Velden A, Reijers M. 2016. The 'Botanical Gardens of the Dispossessed' revisited: richness and significance of Old-World crops grown by Suriname Maroons. Genetic Resources and Crop Evolution 63(4):695710.

Van Andel TR, van't Klooster Cl, Quiroz D, Towns AM, Ruysschaert S, van den Berg M. 2014. Local plant names reveal that enslaved Africans recognized substantial parts of the New World flora. Proceedings of the National Academy of Sciences 111(50):E5346-E5353.

Van Andel T, Veltman MA, Bertin A, Maat H, Polime T, Hille Ris Lambers D, Tjoe Awie J, De Boer H, Manzanilla V. 2019. Hidden rice diversity in the Guianas. Frontiers in Plant Science 20(10):1161.

Viladrich A. 2006a. Beyond the supernatural: Latino healers treating Latino immigrants in NYC. Journal of Latino/Latin American Studies 2:156-70.

Viladrich A. 2006b. Botánicas in America's backyard: Uncovering the world of Latino healers' herb-healing practices in New York City. Human Organization 65(4):407-19.

Voeks RA 1997. Sacred Leaves of Candomblé: African Magic, Medicine, and Religion in Brazil. University of Texas Press, Austin, TX, 256p.

Weckmüller H, Barriocanal C, Maneja R, Boada M. 2019. Factors affecting traditional medicinal plant knowledge of the Waorani, Ecuador. Sustainability 11(16): 4460. doi: 10.3390/su11164460

Wunderlin, RP, Hansen BF, Franck AR., Essig. FB. 2021. Atlas of Florida Plants (http://florida.plantatlas.usf.edu/). [S. M. Landry and K. N. Campbell (application development), USF Water Institute.] Institute for Systematic Botany, University of South Florida, Tampa. Accessed 9 Jan 2021. 